\title{
COMPARISON OF SEISMIC RESISTANCE OF HIGHWAY BRIDGE IN YUNNAN BY THE SPECIFICATION OF CHINA AND JAPAN
}

\author{
Wang Lei ${ }^{1} \cdot$ Osamu KIYOMIYA ${ }^{2} \cdot$ Tongxiang $\mathrm{An}^{3}$ \\ ${ }^{1}$ Visiting Researcher, Dept.of Civil and Environmental Eng., Waseda University, \\ Engineer, China Yunnan Province Communication Planning Design and Research Institution, \\ (Shijiaxiang 9, Tuodong Ave., Kunming City, Yunnan Province, 650011, China) \\ E-mail:WL516544@163.com \\ ${ }^{2}$ Fellow of JSCE, Professor, Dept.of Civil and Environmental Eng., Waseda University, \\ (Ohkubo 3-4-1, Shinjuku-ku, Tokyo 169-8555, Japan) \\ E-mail:k9036@waseda.jp \\ ${ }^{3}$ Member of JSCE, Research Associate of Advanced Res. Inst. for Sci. and Eng., Waseda University, \\ (Ohkubo 3-4-1, Shinjuku-ku, Tokyo 169-8555, Japan) \\ E-mail:antongxiang@ybb.ne.jp
}

\begin{abstract}
Yunnan province is one of the populated areas in China where earthquakes have frequently happened especially in recent years, meanwhile a large number of highway bridges have been designed and constructed in Yunnan, whose seismic resistance design is implemented according to the <Specifications of Earthquake Resistant Design for Highway Engineering>(JTJ004-89). Since October $1^{\text {st }} 2008$ the <Guidelines for Seismic Design of Highway Bridge> (JTG/T B02-01-2008) has been released, that has radically revised the guiding concept and performance requirement for the bridge seismic design. Then what level the bridges that have been designed and constructed before the date line are at according to the revised specification, what level according to the current <Specification for Japanese Highway Bridges> that is considered more advanced in the world, and what are the differences between the Chinese specification and the Japanese one are studied. In this paper, a representative expressway bridge in Yunnan respectively according to the Chinese old, revised specifications and Japanese specification is analyzed. This calculation brings some helps to the construction of the highway bridge in Yunnan.
\end{abstract}

Key Word: Bridge in Yunnan, earthquake activity, nonlinear dynamic analysis, response spectrum, seismic specification for highway bridges

\section{INTRODUCTION}

Yunnan province lies in the southwest of China, border Burma, Laos and Vietnam at south, as shown in Fig.1. and Fig.2.

Yunnan province is one of the concentrative areas in China where earthquakes have frequently happened. In recorded history, magnitude 8 and 7-7.9 earthquakes happened 9 times and 78 times respectively. In the 46 years from 1950 to 1995 over magnitude 5 earthquakes totally happened 202 times, averagely 5 times per year, among them over magnitude 6 ones were 41 times and over magnitude 7 were 6 times, the frequency is highest in China. It can be seen in Fig.3. and Fig.4. The Table 1. and Table 2. list the earthquakes happened in modern times in Yunnan. Frequent earthquakes are considered caused by the geographical position: Yunnan lies in the

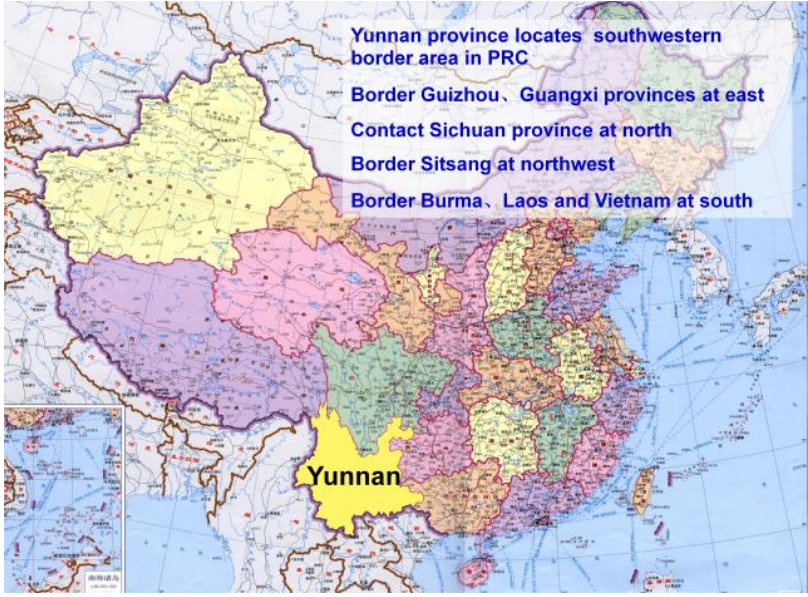

Fig.1 Yunnan location in China 


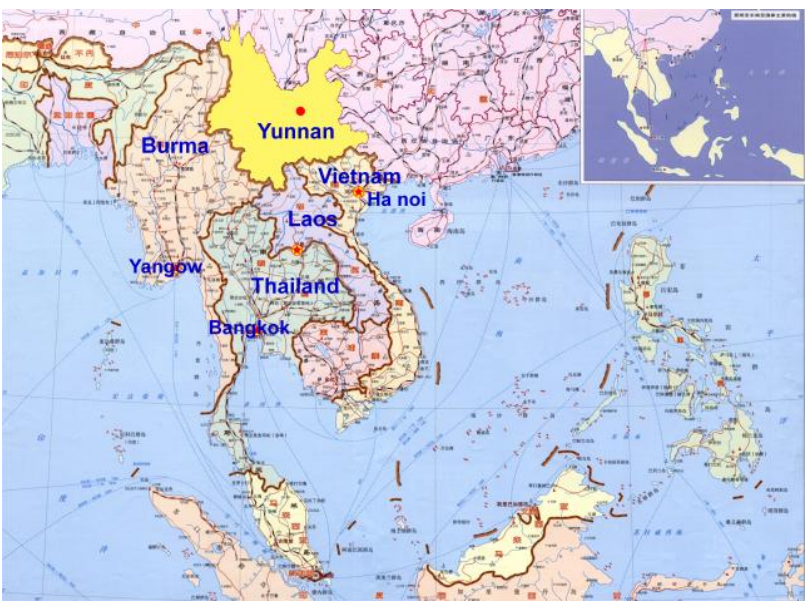

Fig.2. Yunan location in Southeast Asian

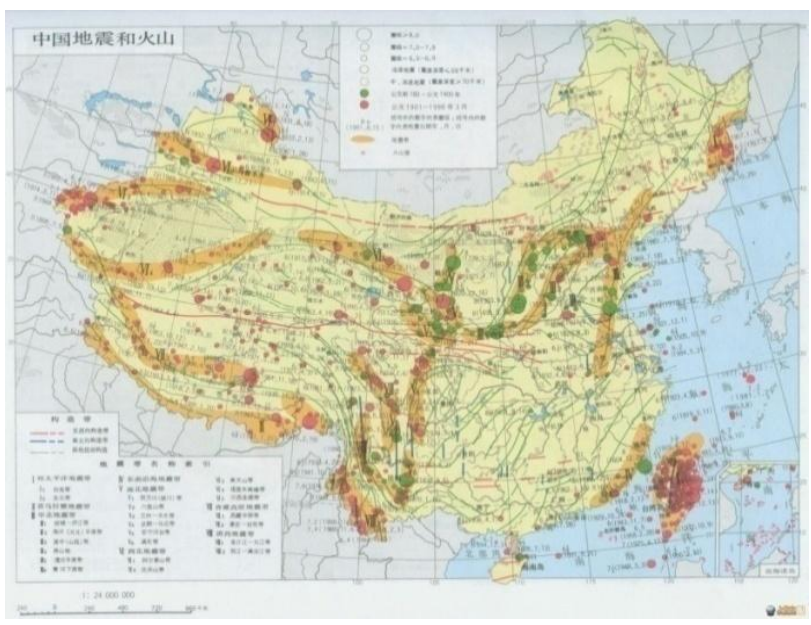

Fig. 3. Distribution of main seismic belts in China

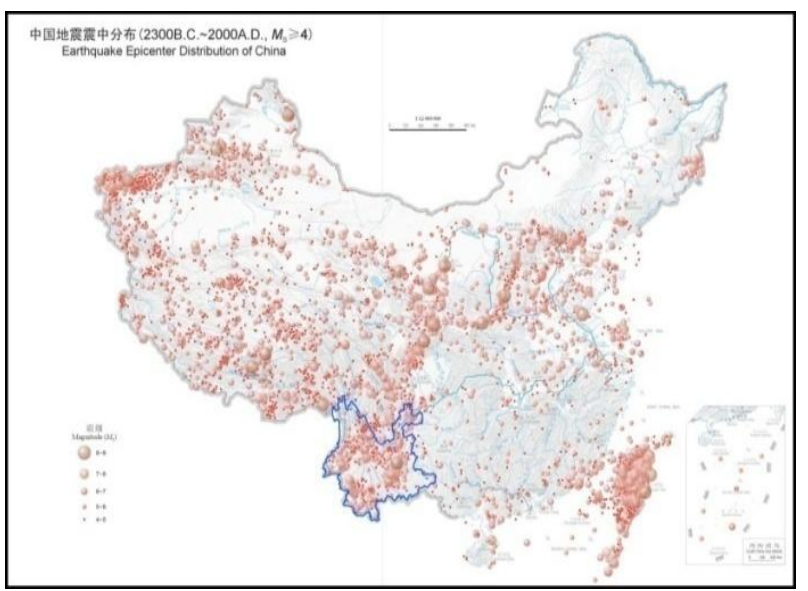

Fig. 4. 2300B.C.-2000A.D. epicenter distribution of over magnitude 4 earthquakes in China

southwest seismic belt that is the primary seismic belt of China, and also lies in the Himalayas-Mediterranean seismic belt that is one of the two main seismic belts in the world, whose diastrophism is so severe on the globe under the double effects of the subduction by Indian plate towards to east and the lateral extrusion of QinghaiTibet block.
Table 1. Catalog of over magnitude 6 earthquakes in 1949-2007 in Yunnan

\begin{tabular}{|c|c|c|c|}
\hline No & Time & Location & $\begin{array}{c}\text { Magnitude } \\
\mathrm{M}_{\mathrm{s}}\end{array}$ \\
\hline 1 & 1951.12 .21 & Jianchuan, Heqing & 6.3 \\
\hline 2 & 1966.2 .5 & Dongchuan & 6.5 \\
\hline 3 & 1970.1.5 & $\begin{array}{c}\text { Tonghai,Eshan,Jianshui, } \\
\text { Yuxi,Shiping }\end{array}$ & 7.7 \\
\hline 4 & 1974.5.11 & Daguan, Yongshan & 7.1 \\
\hline 5 & 1976.5.29 & Longlin, Luxi & 7.4 \\
\hline 6 & 1985.4 .18 & Luquan, Xundian & 6.3 \\
\hline 7 & 1988.11.6 & Cangyuan, Genma & 7.6 \\
\hline 8 & 1995.6.30 & Menglian & 7.3 \\
\hline 9 & 1995.10.24 & Wuding & 6.5 \\
\hline 10 & 1996.2.3 & Lijiang & 7.0 \\
\hline 11 & 1998.11.19 & Ninglang & 6.2 \\
\hline 12 & 2000.1 .15 & Yaoan & 6.5 \\
\hline 13 & 2001.4.12 & Shidian & 5.9 \\
\hline 14 & 2001.10.27 & Yongsheng & 6.0 \\
\hline 15 & 2003.7 .21 & Dayao & 6.2 \\
\hline 16 & 2004.8 .10 & Nudian & 5.6 \\
\hline 17 & 2006.7.22 & Yanjing & 5.1 \\
\hline 18 & 2007.6 .3 & Ninger & 6.4 \\
\hline
\end{tabular}

Table 2. Catalog of earthquakes in 2008 in Yunnan

\begin{tabular}{|c|c|c|c|}
\hline No. & Time & Location & $\begin{array}{c}\text { Magnitude } \\
\mathrm{M}_{\mathrm{s}}\end{array}$ \\
\hline 1 & 2008.8 .21 & Yingiang & 5.9 \\
\hline 2 & 2008.8 .30 & Yongren,Panzhihua & 6.1 \\
\hline 3 & 2008.10 .8 & Yuanmou & 4.5 \\
\hline 4 & 2008.12 .26 & Ruili & 4.9 \\
\hline 5 & 2008.12 .26 & Yiliang (Kunming) & 4.3 \\
\hline
\end{tabular}

The main secondary seismic belts in Yunnan are: (1) Mabian-Daguan; (2) Xiaojiang; (3) Tonghai-Shipin;

(4) Tengcong-Longlin; (5) Genma-Lancang; (6) SimaoPuer. The earthquakes happened in these secondary seismic belts are characterized by high frequency and intensity, shallow seismic source and widely distribution. Furthermore in recent years there are more and more active crustal movement tendency discovered and several times severely destructive earthquakes already happened in the area. The epicenter of Wencuan earthquake in May $12^{\text {nd }}, 2008$ lies less than $600 \mathrm{~km}$ to Yunnan.

On the other hand, Yunnan has tremendously developed its highway infrastructure in recent 15 years under the National Strategy of Developing the Western Region. By the year of 2008, the total length of highway has reached 198.5 thousand kilometers, among them 2500 kilometers is expressway. Fig.5. is the distribution 
of the backbone highways in Yunnan. Among them the bridge and tunnel have more share along highway in Yunnan for its mountainous terrain. For example its proportion has reached $47.9 \%$ in Shuifu Maliuwan expressway in the northwest of Yunnan. As an important component of highway net, Bridge plays momentous function in social and economic development, also plays a life-and-death role in seismic relief and reconstruction. However bridge also is the anti-earthquake weakness among various highway infrastructures for its structural characteristic. So it is considered necessary that the more attention is paid to improve the seismic resistance of bridges in Yunnan and guarantee their safety.

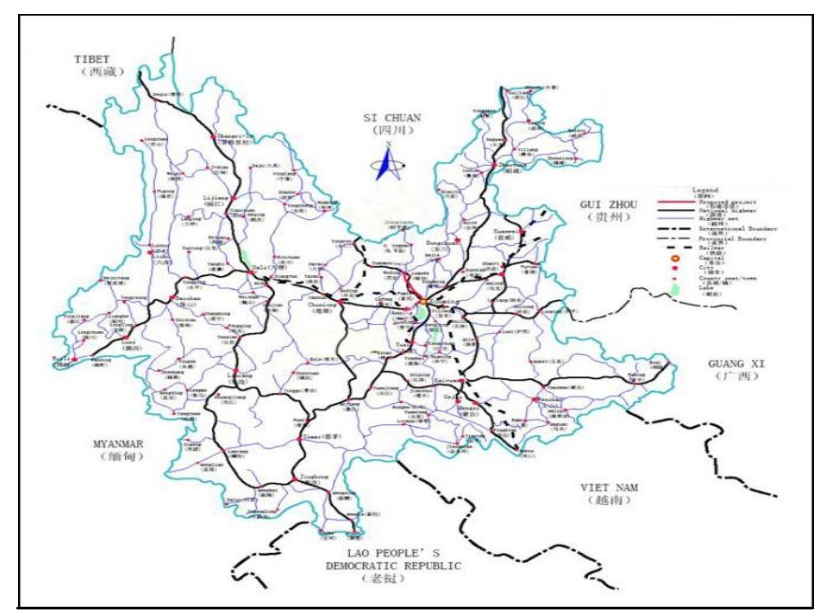

Fig.5. Distribution of highways in Yunnan

\section{THE ESSENTIAL OF CHINESE SEISMIC SPECIFICATION}

During the period from Jan. $1^{\text {st }} 1990$ to Set. $30^{\text {th }} 2008$ the bridge seismic design was carried out in China according to the <Specification of Earthquake Resistant Design for Highway Engineering>JTJ044-089 (the $<$ China JTJ044-089> is abbreviated in the following) that was concluded from Tangshan Earthquake happened in Jul. $28^{\text {th }} 1976$. From Oct. $1^{\text {st }} 2008$ the revised vision called <Guidelines for Seismic Design of Highway Bridge > JTG/T B02-01-2008(the <China JTG/T B02-01$2008>$ is abbreviated in the following) was published as a recommended occupation standard. In some level the revised version embodies many newest seismic theories in the world. The essentials of the two specifications are summarized as the following.

(1)The <China JTJ044-089>

The earthquake force according to the provisions concerned is defined as the following equation:

$$
E_{\text {ihp }}=C_{i} C_{z} K_{h} B_{i} Y_{i} X_{i i} G_{i}
$$

Where $E_{\mathrm{ihp}}$ is horizontal earthquake force $(\mathrm{kN})$ acting upon the No. i node of the column that has been discretized by the finite element method; $\mathrm{C}_{\mathrm{i}}$ is the importance modified coefficient; $\mathrm{K}_{\mathrm{h}}$ is the horizontal earthquake coefficient (the areal coefficient); $Y_{i}$ is the participation coefficient of the fundamental mode; $X_{i i}$ is the relative horizontal displacement of the center of gravity of the No. i element of column; $G_{i}$ is the gravity of the No. $i$ element of column; $B_{i}$ is the dynamic modified coefficient of the fundamental period and is shown in Fig.6.; $\mathrm{T}$ is the fundamental period of the construction; $\mathrm{C}_{\mathrm{z}}$ is the general influence coefficient and is listed in Table 4.

In addition, the design frequency is considered as shown in Table 3.

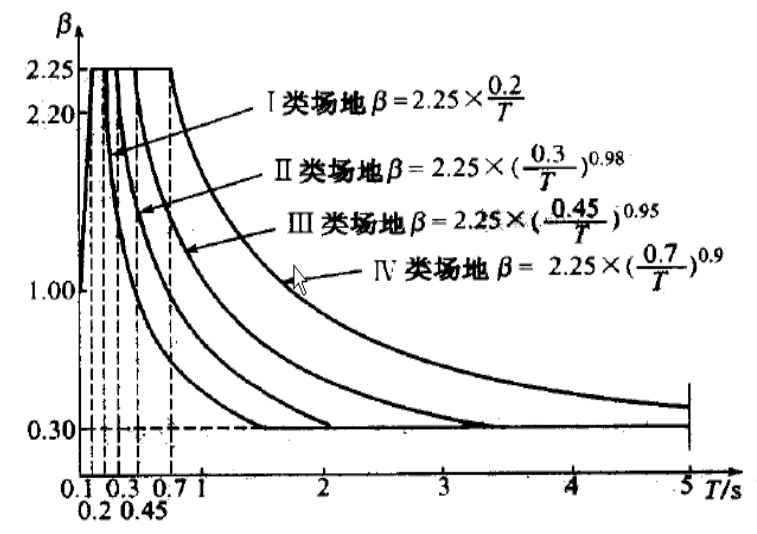

Fig. 6. Dynamic modified coefficient

Table 3. Design periods (years)

\begin{tabular}{|c|c|c|c|c|c|}
\hline \multirow{2}{*}{$\begin{array}{c}\text { Importance modified } \\
\text { coefficient }\left(\mathrm{C}_{\mathrm{i}}\right)\end{array}$} & \multicolumn{5}{|c|}{ General influence coefficient $\left(\mathrm{C}_{\mathrm{Z}}\right)$} \\
\cline { 2 - 6 } & 0.20 & 0.25 & 0.30 & 0.33 & 0.35 \\
\hline 1.7 & 50 & 75 & 106 & 129 & 147 \\
\hline 1.3 & 31 & 46 & 64 & 76 & 85 \\
\hline 1.0 & 21 & 29 & 40 & 47 & 52 \\
\hline 0.6 & 10 & 13 & 17 & 20 & 22 \\
\hline
\end{tabular}

Table 4. General influence coefficient $\left(\mathrm{C}_{\mathrm{Z}}\right)$

\begin{tabular}{|c|c|c|c|c|c|}
\hline \multirow{2}{*}{\multicolumn{3}{|c|}{ Classification by the bridge type, column and abutment }} & \multicolumn{3}{|c|}{ Height of column: $\mathrm{H}(\mathrm{m})$} \\
\hline & & & $\mathrm{H}<10 \mathrm{~m}$ & $10 \leq \mathrm{H}<20$ & $20 \leq \mathrm{H}<30$ \\
\hline \multirow{4}{*}{$\begin{array}{l}\text { Beam } \\
\text { bridge }\end{array}$} & Flexible pier & Column pier、 pile bent pier、 thin walled pier & 0.30 & 0.33 & 0.35 \\
\hline & Gravity pier & $\begin{array}{l}\text { Gravity pier that lies on the natural foundation } \\
\text { or the open caisson foundation }\end{array}$ & 0.20 & 0.25 & 0.30 \\
\hline & \multicolumn{2}{|r|}{ Column that lies on the multiple row piles } & 0.25 & 0.30 & 0.35 \\
\hline & \multicolumn{2}{|c|}{ Abutment } & \multicolumn{3}{|c|}{0.35} \\
\hline \multicolumn{3}{|r|}{ Arch bridge } & \multicolumn{3}{|c|}{0.35} \\
\hline
\end{tabular}


Table 5. Performance level in the <China JTJ044-089>

\begin{tabular}{|l|l|}
\hline \multicolumn{1}{|c|}{ Project category } & \multicolumn{1}{|c|}{ Performance level } \\
\hline $\begin{array}{l}\text { The works of Expressway and Class I Highway that lie on the areas with common } \\
\text { geology condition }\end{array}$ & $\begin{array}{l}\text { Can be normally used after be commonly } \\
\text { repaired }\end{array}$ \\
\hline $\begin{array}{l}\text { The works of Expressway and Class I Highway that lie on the areas with soft } \\
\text { cohesive soil layers or liquefied soil layers } \\
\text { The works of Class II Highway that lie on the areas with common geology condition }\end{array}$ & $\begin{array}{l}\text { Capable of recovering functions by } \\
\text { emergency repair works within a short period }\end{array}$ \\
\hline $\begin{array}{l}\text { The works of Class III or Class IV Highway } \\
\text { The works of Class II Highway that lie on the areas with soft cohesive soil layers or } \\
\text { liquefied soil layers } \\
\text { The works of Expressway, Class I and Class II Highway that lie on the faulted zones } \\
\text { and their vicinity with high-risk geologic hazard }\end{array}$ & $\begin{array}{l}\text { Bridges, tunnels and other important } \\
\text { constructions can avoid serious damage }\end{array}$ \\
\hline
\end{tabular}

Table 6. Performance level in the <China JTG/T B02-01-2008>

\begin{tabular}{|c|c|c|}
\hline \multirow{2}{*}{$\begin{array}{l}\text { Performance } \\
\text { level }\end{array}$} & \multicolumn{2}{|r|}{ Performance Purpose } \\
\hline & E1 effect & E2 effect \\
\hline A Class & $\begin{array}{l}\text { No damage or can be } \\
\text { used without repair }\end{array}$ & Only insignificant damage and can be used after easy repair or without repair \\
\hline B Class & Same as above & \multirow{2}{*}{$\begin{array}{l}\text { To sure no collapse or serious damage and is capable of recovering functions to meet } \\
\text { emergency by temporary reinforce }\end{array}$} \\
\hline C Class & Same as above & \\
\hline D Class & Same as above & \\
\hline
\end{tabular}

\section{(2)The <China JTG/T B02-01-2008>}

The performance level in the specification is shown in Table 6.

As far as the analysis method, there is only exercisable and definite provisions and explication on the response spectrum method to calculate earthquake force upon bridge, while by the time-history method and the power spectrum method there are only some macroscopic principles refered.

When the structural dumping ratio is 0.05 , the response spectrum of the horizontal design acceleration is definite as Fig 7.

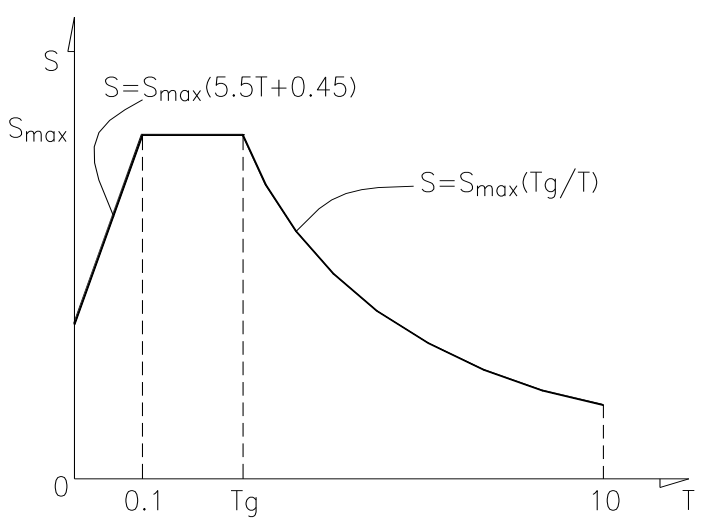

Fig. 7. Design response spectrum of the horizontal acceleration

Where (a) $S_{\max }$ is the maximum value of the horizontal design acceleration and it is given as the following equation.

$$
\mathrm{S}_{\max }=2.25 \mathrm{C}_{\mathrm{i}} \mathrm{C}_{\mathrm{s}} \mathrm{C}_{\mathrm{d}} \mathrm{A}
$$

In equation (2), $C_{i}$ is the importance modified coefficient, $\mathrm{C}_{\mathrm{s}}$ is the site coefficient as shown in Table 7. $\mathrm{C}_{\mathrm{d}}$ is the dumping modified coefficient; $\mathrm{A}$ is the peak value of the earthquake acceleration with the corresponding design intensity as shown in Fig.8.

(b) $\mathrm{T}_{\mathrm{g}}$ is the site characteristic period listed in Table 8., in that the representational value is defined in Fig.9. by the location in this map.

(c) $\mathrm{T}$ is the natural period of the structure vibration.

The design period of the specification is considered as shown in Table 9.

Table 7. Site coefficients $\left(\mathrm{C}_{\mathrm{s}}\right)$

\begin{tabular}{|c|c|c|c|c|c|c|}
\hline \multirow{2}{*}{$\begin{array}{c}\text { Site } \\
\text { category }\end{array}$} & \multicolumn{6}{|c|}{ Basic intensity } \\
\cline { 2 - 7 } & 6 & \multicolumn{2}{|c|}{7} & \multicolumn{2}{|c|}{8} & 9 \\
\cline { 2 - 7 } & $0.05 \mathrm{~g}$ & $0.1 \mathrm{~g}$ & $0.15 \mathrm{~g}$ & $0.2 \mathrm{~g}$ & $0.3 \mathrm{~g}$ & $0.4 \mathrm{~g}$ \\
\hline I & 1.2 & 1.0 & 0.9 & 0.9 & 0.9 & 0.9 \\
\hline II & 1.0 & 1.0 & 1.0 & 1.0 & 1.0 & 1.0 \\
\hline III & 1.1 & 1.3 & 1.2 & 1.2 & 1.0 & 1.0 \\
\hline IV & 1.2 & 1.4 & 1.3 & 1.3 & 1.0 & 0.9 \\
\hline
\end{tabular}

Table 8. Modified value of characteristic period (s)

\begin{tabular}{|c|c|c|c|c|}
\hline \multirow{2}{*}{$\begin{array}{c}\text { Representational value of the } \\
\text { Characteristic period in zoning } \\
\text { map (s) }\end{array}$} & \multicolumn{4}{|c|}{ Site category } \\
\cline { 2 - 5 } & I & II & II & IV \\
\hline 0.35 & 0.25 & 0.35 & 0.45 & 0.65 \\
\hline 0.40 & 0.30 & 0.40 & 0.55 & 0.75 \\
\hline 0.45 & 0.35 & 0.45 & 0.65 & 0.90 \\
\hline
\end{tabular}


中国地震动峰值加速度区划图

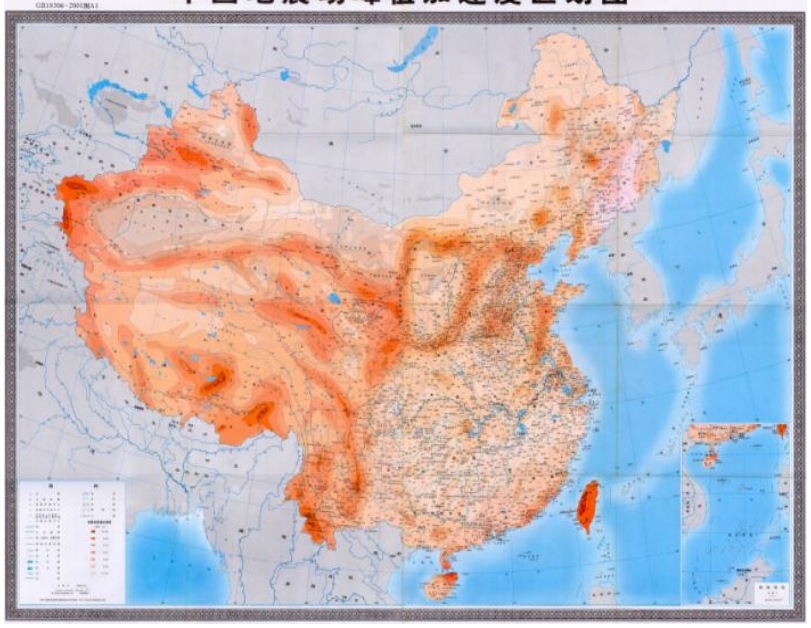

Fig. 8. China earthquake peak value acceleration zoning map

\section{COMPARISON OF PARAMETERS IN SEISMIC SPECIFICATIONS}

The <Specification for Highway Bridges, Part V Seismic Design> (the <Japan JRA-2002> is abbreviated in the following) is implemented in bridge seismic design in Japan, that is established on the experience of HANSIN earthquake. The comparison of the major parameters in the specifications of China and Japan is shown in Table 10.

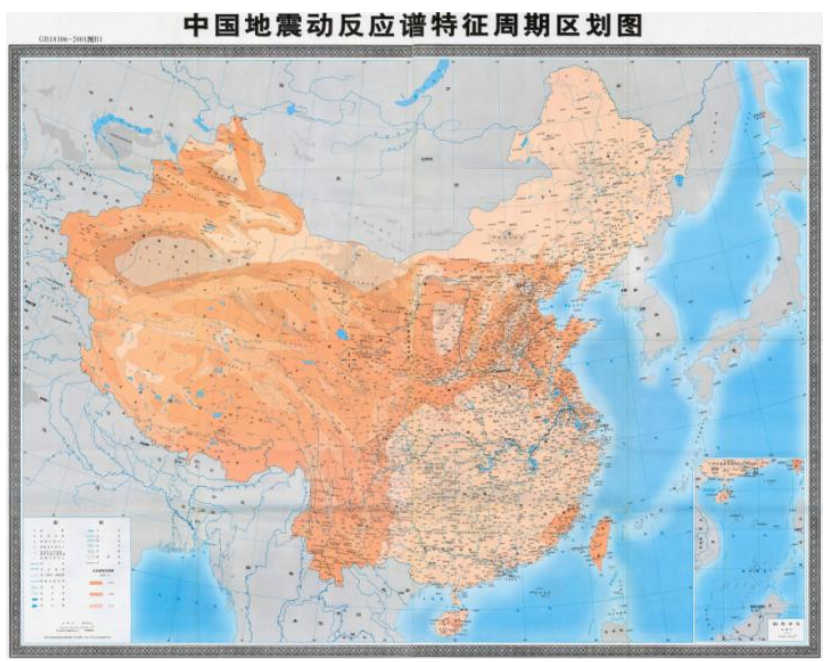

Fig.9. China earthquake characteristic period of response spectrum zoning map

Table 9. Design Period (years)

\begin{tabular}{|c|c|c|}
\hline Earthquake level & E1 & E2 \\
\hline Performance level & 475 & 2000 \\
\hline B,C & $50-100$ & $475-2000$ \\
\hline D & 25 & -- \\
\hline
\end{tabular}

Table 10. Comparison of main parameters in the seismic specifications

\begin{tabular}{|c|c|c|c|c|}
\hline Specification & China JTJ044-089 & \multicolumn{2}{|c|}{ China JTG/T B02-01-2008 } & Japan JRA-2002 \\
\hline Performance level & 4 classes by importance coefficient & \multicolumn{2}{|c|}{$A 、 B 、 C 、 D$} & A、B \\
\hline Site classification & I、II、III、IV* & \multicolumn{2}{|c|}{ I、II、III、IV** } & I、II、III** \\
\hline $\begin{array}{l}\text { Areal coefficient } \\
\text { (reflects seismic } \\
\text { intensity) }\end{array}$ & $\begin{array}{cc}\text { Magnitude 6:simply performance } \\
\text { Magnitude 7: } & 0.1 \\
\text { Magnitude 8: } & 0.2 \\
\text { Magnitude 9: } & 0.4\end{array}$ & \multicolumn{2}{|c|}{$\begin{array}{c}\text { Magnitude } 6: 0.05 \mathrm{~g} \\
\text { Magnitude 7: } 0.10 \mathrm{~g} \text { or } 0.15 \mathrm{~g} \\
\text { Magnitude 8: } 0.20 \mathrm{~g} \text { or } 0.30 \mathrm{~g} \\
\text { Magnitude 9: } 0.40 \mathrm{~g}\end{array}$} & $\begin{array}{l}\text { A zone: } C_{Z}=1.0 \\
\text { B zone: } C_{Z}=0.85 \\
\text { C zone: } C_{Z}=0.7\end{array}$ \\
\hline \multirow[b]{2}{*}{$\begin{array}{l}\text { Importance } \\
\text { modified coefficient }\end{array}$} & & E1 & E2 & \multirow[b]{2}{*}{$\begin{array}{l}\text { Embodied in evaluation of } \\
\text { seismic resistance of the } \\
\text { two performance levels } \\
\text { (A or B). }\end{array}$} \\
\hline & $\begin{array}{l}1.7 \\
1.3 \\
1.0 \\
0.6\end{array}$ & $\begin{array}{c}1.0 \\
0.43(0.50) \\
0.34 \\
0.23\end{array}$ & $\begin{array}{c}1.7 \\
1.3(1.7) \\
1.0 \\
\text { Non }\end{array}$ & \\
\hline $\begin{array}{l}\text { Damping modified } \\
\text { coefficient }\left(\mathrm{C}_{\mathrm{d}}\right)\end{array}$ & No mentioned & \multicolumn{2}{|c|}{$\begin{array}{c}\mathrm{C}_{\mathrm{d}}=1+\frac{0.05-\xi}{0.06+1.7 \xi} \geq 0.55 \\
\text { Commonly } \xi=0.05, \\
\text { So } \mathrm{C}_{\mathrm{d}}=1.0\end{array}$} & $\begin{array}{c}\mathrm{C}_{\mathrm{D}}=\frac{1.5}{40 \mathrm{~h}+1}+0.5 \\
\text { When } \mathrm{h}=0.05 \\
\mathrm{C}_{\mathrm{D}}=1.0\end{array}$ \\
\hline $\begin{array}{l}\text { Definitely analytic } \\
\text { method }\end{array}$ & $\begin{array}{l}\text { Single mode response spectrum } \\
\text { method }\end{array}$ & \multicolumn{2}{|c|}{$\begin{array}{l}\text { Multimode response spectrum } \\
\text { method }\end{array}$} & $\begin{array}{l}\text { Seismic coefficient method } \\
\text { Ductility design method } \\
\text { Dynamic analysis }\end{array}$ \\
\hline \multicolumn{5}{|c|}{$\begin{array}{l}\text { Note:* Definited by the description of the properties, the component and the allowable bearing capacity of the foundation soil } \\
\text { layers; } \\
\text { ** Definited by the average velocity of the shear wave transmitting in the soil layers and their thickness. }\end{array}$} \\
\hline
\end{tabular}




\section{DESCRIPTION OF SEISMIC ANALYSIS PROCEDURE}

$\mathrm{T}$ shaped continuous beam bridge has several significant advantages: various choices of span and flexible applicability $(20 \mathrm{~m}, 25 \mathrm{~m}, 30 \mathrm{~m}$ and $40 \mathrm{~m}$ per span is widely used), saving cost, convenient structure for lighter erection weight, abundant experience and good travel comfort. Due to these advantages, it is in large amounts structured in high level highway in combination with the actual circumstances in Yunnan. In common case the proportion can have been over $60 \%$ in total bridges.

The $\mathrm{K} 138+800$ bridge lies in the contract B15 of Qiliqing section along Yuanmou Wuding expressway that is a section of Lanzhou Mohan highway as the backbone highway for the Develop Western Regions Strategy. It has been open to traffic on Nov. $28^{\text {th }} 2008$. As the Fig.10. shown, its superstructure is $\mathrm{T}$ shaped continuous beam and 7 spans (30m per-span) with a total length of $218 \mathrm{~m}$ and width of $24.5 \mathrm{~m}$, and is two-way 4 lanes by two separated structures for each way. It lies in long radius plan and profile curve of the route. The superstructure in each way is continuous beam for travel comfort and with 2 FD-80 expansion joints is connected with the gravity abutments in both sides. It can be seen in Fig.11., the substructure is twin circle columns and piles, whose diameter are $1.5 \mathrm{~m}$ and $1.6 \mathrm{~m}$ respectively. The two columns connected by the bent cap and the tie beam form framework in the cross bridge axial direction. The reinforcement detail for column and pile is shown in Fig.12.

The K138+800 bridge has broadly representative as far as its span, form of components, dimension of column and geology condition concerned. The left way is selected as the subject to analyze. Furthermore the structure in the cross bridge axial direction has stronger seismic resistance than it in the bridge axial direction, in this paper only the resistance in the bridge axial direction is evaluated and all columns will be looked as socle beams.

\section{(1)Model building}

The structure is discretized and the computation module is built as Fig.13.

The 5 beams are replaced to a linear beam. And as shown in the Fig.14., the 10 rubber bearings under the end of each span on the bent cap on column are replaced to the 5 linear spring elements in horizontal direction to link the beam with the bent cap. The horizontal spring stiffness $\mathrm{K}(\mathrm{kN} / \mathrm{m})$ is defined by the following equation:

$$
\mathrm{K}=\mathrm{G}_{\mathrm{d}} \mathrm{A}_{\mathrm{r}} / \sum \mathrm{t}
$$

Where $G_{d}$ is the dynamic shear modulus of the bearing $\left(\mathrm{kN} / \mathrm{m}^{2}\right), \mathrm{A}_{\mathrm{r}}$ is the shear area $\left(\mathrm{m}^{2}\right), \sum \mathrm{t}$ is the total thickness of all rubber layers of every support $(\mathrm{m})$. The 5 sliding plate bearing under the end of the superstructure on the cap beam of the abutments are replaced to 5 vertical general supports. The deformations of all rubber bearings on the same bent cap or the cap beam are considered equal since only the bridge axial direction horizontally is evaluated.

For linking the beam with the bearing, and the column with the bent cap, the rigid linking style is used. The height difference of the two columns under the same bent cap cased by deck transverse slope is ignored. Every node of the pile is elastically supported in two orthogonal horizontal directions whose spring stiffness is obtained by the characteristic of the earth layers around the pile according to the <Japan JRA-2002>, because there is still not related provisions in the <China JTG/T B02-012008>. Every bottom of the piles is generally supported vertically.

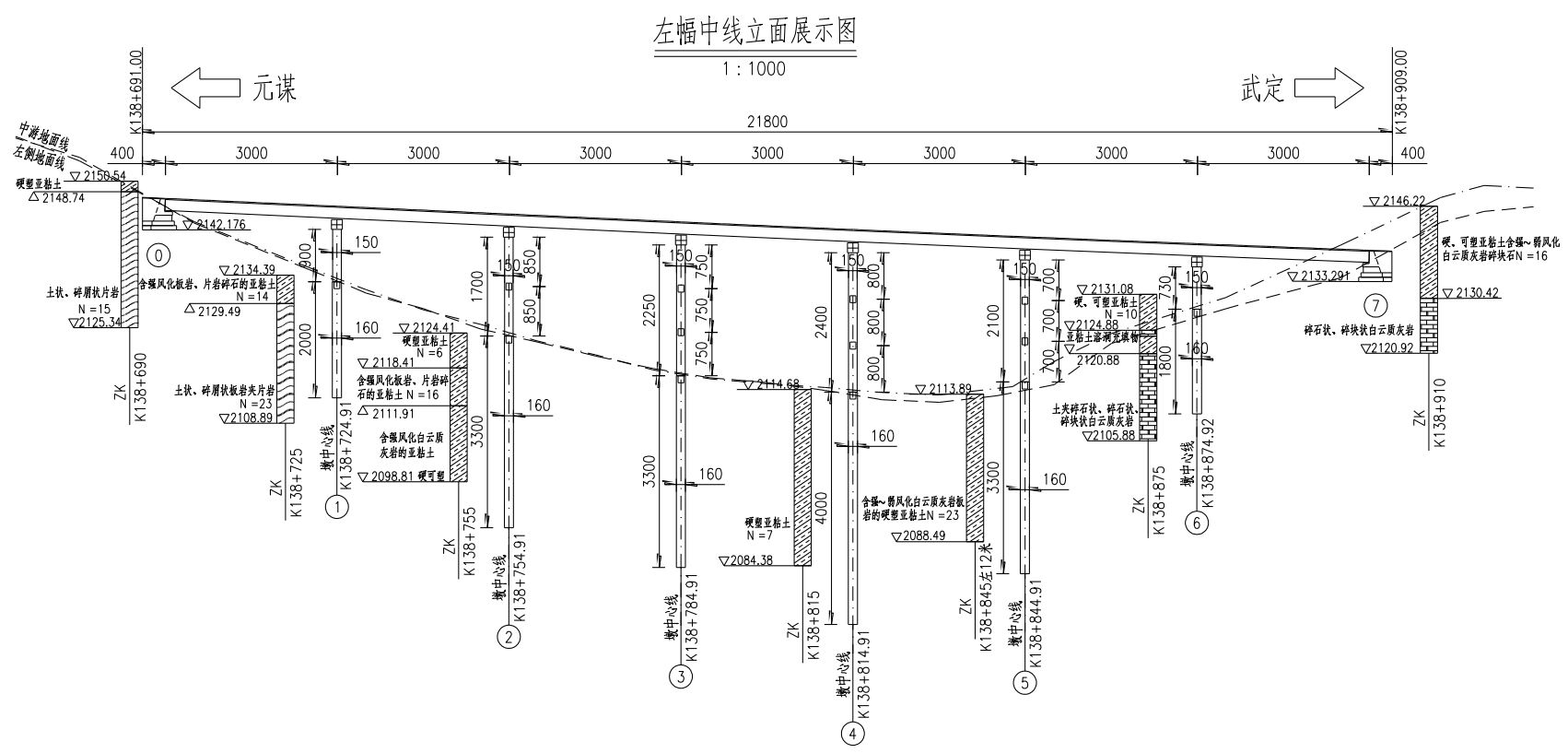

Fig.10. Outline of the K138+800 bridge 


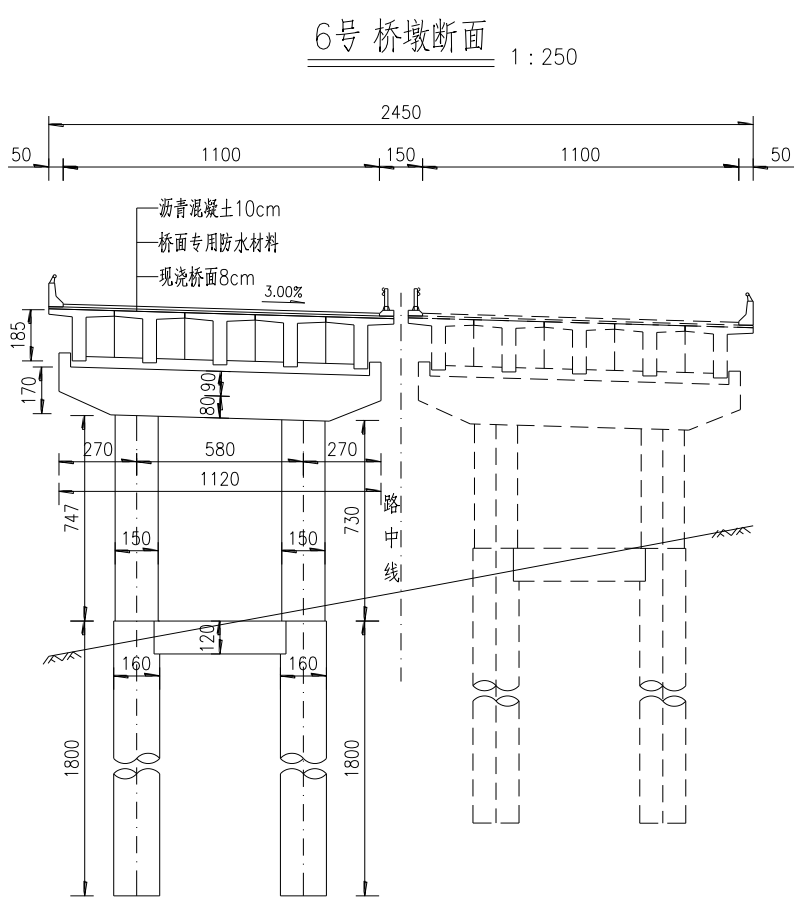

Fig.11. Cross section profile (The No.6 column)

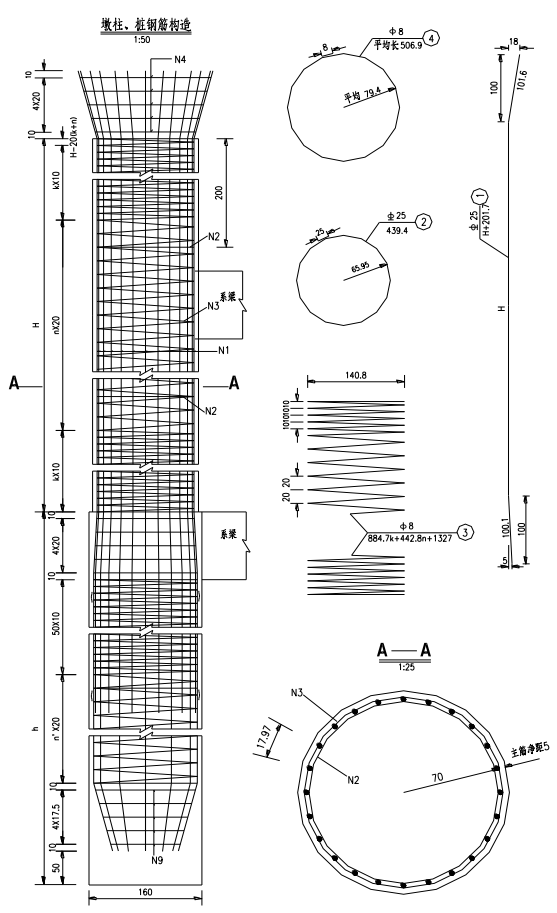

Fig.12. The reinforcement detail for column and pile

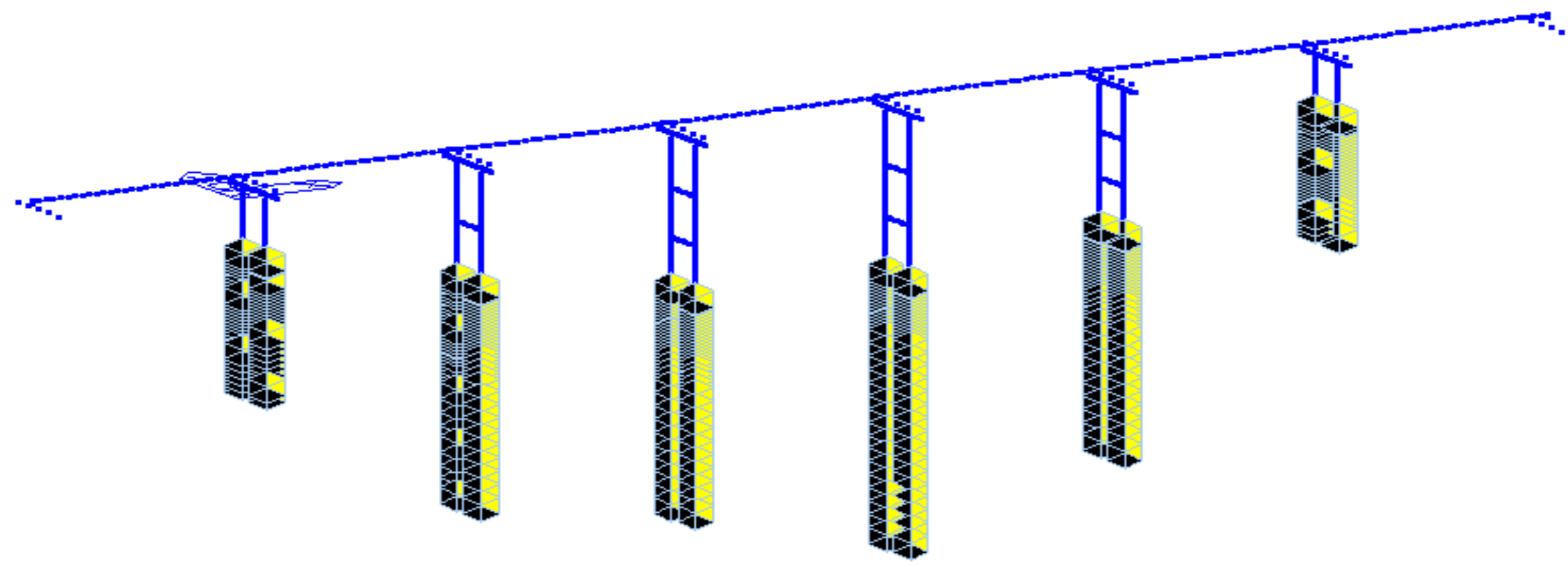

Fig.13. The discretized model by finite elements (elastic linking isn't shown)

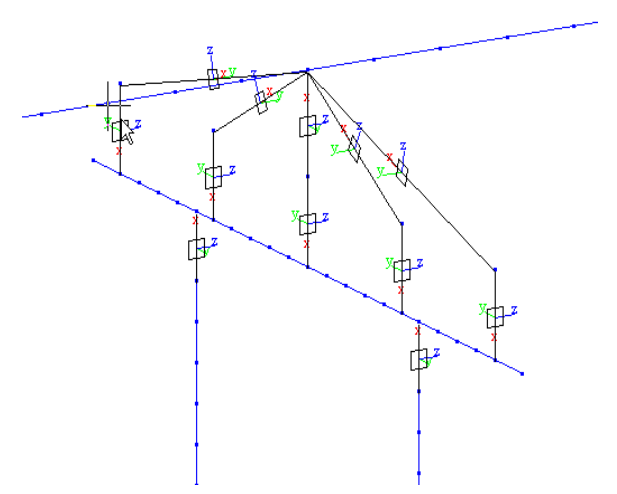

Fig.14. Linkage of between superstructure and Substructure

\section{(2)Inelasticity Characteristic}

Only the elastic stage of a structure can be calculated by the <China JTJ044-089>. As a revised version, the $<$ China JTG/T B02-01-2008> still has no explicit relational expression between stress and strain for reinforcing steel bar and confined concrete when they are considered in nonlinear stage, so that in this paper this functional equation provided by the <Japan JRA-2002> is used. Moreover there is difference of the definition of concrete strength between Chinese specification that use $150 \mathrm{~mm} \times 150 \mathrm{~mm} \times 300 \mathrm{~mm}$ cuboid as standard test piece and Japanese specification that use $\varphi 150 \times 300 \mathrm{~mm}$ and $\varphi 100 \times 200 \mathrm{~mm}$ cylinder as standard one. The designed standard strength of the $\mathrm{C} 30$ concrete of China is equivalently converted to $24(\mathrm{MPa})$ according to the Japanese Specification concerned. 
Table 11. Characteristic values of C30 confined concrete and reinforcing steel bar

\begin{tabular}{|c|c|c|}
\hline Specification & \multirow{2}{*}{ China JTG/T B02-01-2008 } & \multicolumn{2}{|c|}{ Japan JRA-2002 } \\
\cline { 2 - 3 } Type 2 \\
\hline Axial compressive strength of the concrete $(\mathrm{MPa})$ & 20.1 & \multicolumn{2}{|c|}{24} \\
\hline Ultimate strain of the confined concrete $\varepsilon_{c u}$ & 0.00558 & 0.0024633 \\
\hline Peak stress of the confined concrete $f_{c c}^{\prime}(\mathrm{MPa})$ & 25.125 & \multicolumn{2}{|c|}{25.322} \\
\hline Reduced ultimate strain of stirrup $\boldsymbol{\varepsilon}_{s u}^{R}$ & 0.09 & No mentioned \\
\hline Reduced ultimate strain of longitudinal tensile steel bar $\varepsilon_{l u}$ & 0.10 & No mentioned \\
\hline
\end{tabular}

Table 12. Characteristic value of the cross section of the bottom of the No.6 column as an example

\begin{tabular}{|c|c|c|c|}
\hline Specification & China JTG/T & \multicolumn{2}{|c|}{ Japan JRA-2002 } \\
\cline { 3 - 4 } B02-01-2008 & \multicolumn{2}{|c|}{ Type 1 } \\
\hline The defined length of plastic hinge $(\mathrm{m})$ & 0.916 & \multicolumn{2}{|c|}{0.750} \\
\hline Yield curvature of cross section $\phi_{y}(1 / \mathrm{m})$ & 0.0024712 & 0.0024830 & 0.0024830 \\
\hline Ultimate curvature of cross section $\phi_{u}(1 / \mathrm{m})$ & 0.0177500 & 0.0079692 & 0.0088551 \\
\hline Allowable maximum angle of rotation of the plastic hinge $(\mathrm{rad})$ & 0.0069996 & 0.0054910 & 0.0045726 \\
\hline Allowable maximum displacement of the top of the column $(\mathrm{m})$ & 0.1298 & \multicolumn{2}{|c|}{0.0915} \\
\hline
\end{tabular}

In the <JTG/T B02-01-2008>, some isolated design formulas such as the ultimate value of confined concrete and reinforcing steel bar, and the limit values of various nonlinear stages of the cross section of structural member bar are provided. As far as this example evaluated, the results by calculation are shown in Table 11. and Table 12. Obviously it is hard that the structural nonlinear analysis process is reliably implicated especially under the E2 level earthquake only by use of these results.

As shown in table 12., the yield limit of confined concrete defined in the <China JTG/T B02-01-2008> and the <Japan JRA-2002> are similar, but the ultimate limit defined in the <Japan JRA-2002> is more safety. In terms of the allowable maximum of the angle of rotation of the plastic hinge and the displacement of the top of the column, the provisions in the <Japan JRA-2002> is also more safety.

\section{(3)Major parameters involved}

\section{(a)The <China JTJ044-089>}

The earthquake effect to the structure is calculated by the general influence coefficient in Table 13.

Table 13. General influence coefficient $\left(\mathrm{C}_{\mathrm{Z}}\right)$

\begin{tabular}{|c|c|c|c|c|c|c|}
\hline $\begin{array}{c}\text { Serial } \\
\text { number of } \\
\text { columns }\end{array}$ & $1 \#$ & $2 \#$ & $3 \#$ & $4 \#$ & $5 \#$ & $6 \#$ \\
\hline $\begin{array}{l}\text { Height of } \\
\text { columns }(\mathrm{m})\end{array}$ & 10.85 & 18.85 & 24.35 & 25.85 & 22.85 & 9.15 \\
\hline $\begin{array}{c}\text { General } \\
\text { influence } \\
\text { coefficient }\end{array}$ & 0.33 & 0.33 & 0.35 & 0.35 & 0.35 & 0.30 \\
\hline \multicolumn{7}{|c|}{$\begin{array}{l}\text { Note: The height of column is defined from the bottom of } \\
\text { column to the surface of the padstone on bent cap. }\end{array}$} \\
\hline
\end{tabular}

(b)The <China JTG/T B02-01-2008>

The acceleration response spectrums of the design earthquake E1 and E2 are shown in Fig.15. and Fig.16. and their maximum values respectively are $\mathrm{E} 1: \mathrm{S}_{\max }=$ 0.1688 and $E 2: S_{\max }=0.5737$. The first 50 vibration mode shapes are combinated by the CQC method.

\section{(c)The <Japan JRA-2002>}

The bridge is considered belonging to B category. The modification factor for zones is 0.7 for it also is artificially considered the example lies in $\mathrm{C}$ region and the foundation ground belongs to III category for the characteristic value of ground $\mathrm{T}_{\mathrm{G}}=0.627(\mathrm{~s})$.

The natural period under the level1: $\mathrm{T}=2.375(\mathrm{~s})$, the related design horizontal seismic coefficient $\mathrm{K}_{\mathrm{h}}=0.15$ 。

The natural period under the level2: $\mathrm{T}=3.221(\mathrm{~s})$, the related design horizontal seismic coefficient: $\mathrm{K}_{\mathrm{h}}=0.51$ (Type I) and $\mathrm{K}_{\mathrm{h}}=0.42$ (Type II)。

The data from the special seismic investigation and safety evaluation for the bridge site is shortage, so the standard earthquake wave record T2-III-1 recommended by the <Japan JRA-2002> is artificially used for dynamic analysis (Time-history method) after it is modified by the modification factors $\left(\mathrm{C}_{\mathrm{z}}\right)$ for zones of 0.7 .

\section{(4)Structural analysis by low scale earthquake}

The structure is considered to keep in elastic stage under the low scale earthquake and the calculation result is shown in Table 15. Moreover the rubber support deformation is unnecessary to carry out the safety evaluation under the E1 effect according to the <China JTG/TB02-01-2008> and it is done only under the $E_{h p}$ effect according to the <China JTJ044-89> as shown in Table 14. 


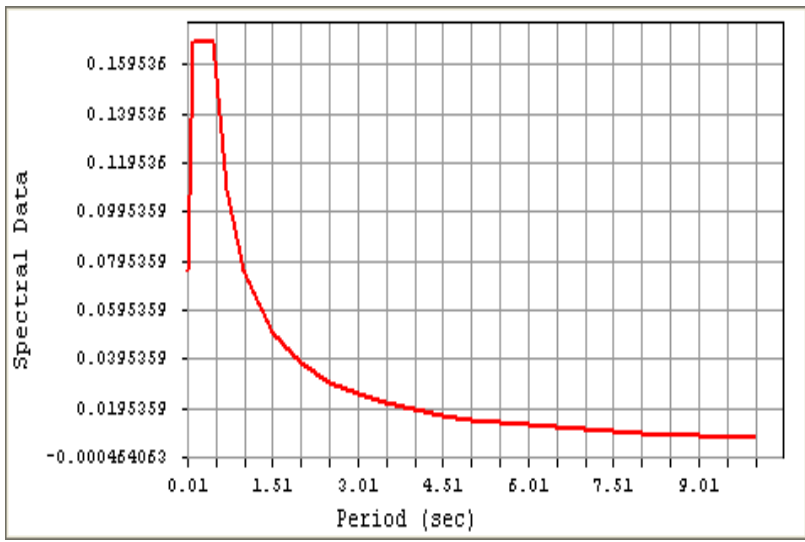

Fig. 15. Response spectrums of E1

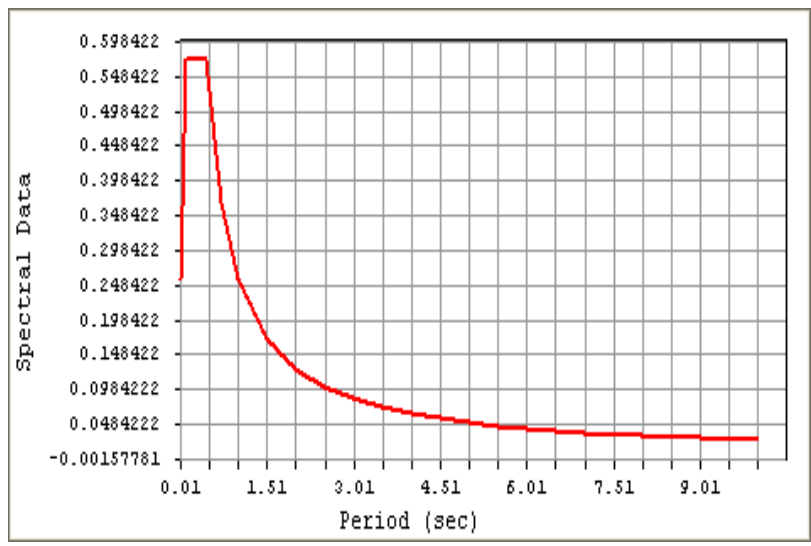

Fig.16. Response spectrums of E2

Table 14. The rubber bearing deformation $(\mathrm{cm})$

\begin{tabular}{|c|c|c|c|c|}
\hline $\begin{array}{l}\text { Bearing location } \\
\text { (the S.N. of } \\
\text { column related) }\end{array}$ & Deformation & $\begin{array}{l}\text { Bearing location } \\
\text { (the S.N. of } \\
\text { column related) }\end{array}$ & Deformation & Safety evaluation \\
\hline 1 & 2.8 & 4 & 0.3 & \multirow{3}{*}{$\begin{array}{l}\text { The permissible maximum deformation of this kind of the } \\
\text { rubber bearing is } 7.7 \mathrm{~cm} \text {, so they're } \mathrm{OK} \text { ! }\end{array}$} \\
\hline 2 & 0.9 & 5 & 0.5 & \\
\hline 3 & 0.4 & 6 & 2.9 & \\
\hline
\end{tabular}

Table 15. Calculation result under low scale earthquake effect

\begin{tabular}{|c|c|c|c|c|c|c|c|c|}
\hline \multirow{3}{*}{$\begin{array}{l}\text { S.N. of } \\
\text { column }\end{array}$} & \multirow{2}{*}{$\begin{array}{c}\text { Axial } \\
\text { pressure } \\
\text { (caused by } \\
\text { gravity) }\end{array}$} & \multicolumn{2}{|c|}{$\begin{array}{c}\mathrm{E}_{\mathrm{hp}} \\
<\text { China JTJ044-89> }\end{array}$} & \multicolumn{2}{|c|}{$\begin{array}{c}\quad \text { E1 } \\
<\text { China JTG/ } \\
\text { TB02-01-2008> }\end{array}$} & \multicolumn{3}{|c|}{$\begin{array}{l}\text { Resistance of the related cross section } \\
\text { related with } \mathrm{E}_{\mathrm{hp}} \text { or } \mathrm{E} 1^{*}\end{array}$} \\
\hline & & $\begin{array}{l}\text { Moment of } \\
\text { the bottom } \\
\text { cross } \\
\text { section }\end{array}$ & $\begin{array}{l}\text { Shearing } \\
\text { force of the } \\
\text { bottom } \\
\text { cross } \\
\text { section }\end{array}$ & $\begin{array}{l}\text { Moment of } \\
\text { the bottom } \\
\text { cross } \\
\text { section }\end{array}$ & $\begin{array}{l}\text { Shearing } \\
\text { force of the } \\
\text { bottom } \\
\text { cross } \\
\text { section } \\
\end{array}$ & $\begin{array}{l}\text { Moment } \\
\text { resistance of } \\
\text { right section }\end{array}$ & $\begin{array}{c}\text { Axial } \\
\text { Resistance } \\
\text { of right } \\
\text { section }\end{array}$ & $\begin{array}{l}\text { Shearing } \\
\text { resistance of } \\
\text { inclined } \\
\text { section }\end{array}$ \\
\hline & $(\mathrm{kN})$ & $(\mathrm{kN}=\mathrm{m})$ & $(\mathrm{kN})$ & $(\mathrm{kN}=\mathrm{m})$ & $(\mathrm{kN})$ & $(\mathrm{kN}=\mathrm{m})$ & $(\mathrm{kN})$ & $(\mathrm{kN})$ \\
\hline 1 & 4497.7 & 2794.2 & 281.8 & 2676.6 & 270.7 & 4682.9 & 6944.9 & 1883.0 \\
\hline 2 & 4390.8 & 1993.9 & 114.3 & 1916.8 & 118.5 & 4867.9 & 7907.0 & 1875.5 \\
\hline 3 & 4870.8 & 1553.3 & 71.5 & 1411.5 & 81.5 & 5089.0 & 9548.8 & 1909.1 \\
\hline 4 & 4918.7 & 1422.3 & 62.8 & 1301.2 & 77.2 & 5131.9 & 10038.8 & 1912.5 \\
\hline 5 & 4658.7 & 1699.0 & 82.3 & 1549.0 & 90.6 & 4986.9 & 8680.4 & 1894.3 \\
\hline 6 & 4426.9 & 2400.0 & 291.5 & 2536.7 & 309.2 & 4972.5 & 8576.5 & 1878.1 \\
\hline
\end{tabular}

(continue)

\begin{tabular}{|c|c|c|c|c|}
\hline \multicolumn{2}{|c|}{$\begin{array}{c}\text { Level1 } \\
\text { (Japan JRA-2002) }\end{array}$} & \multicolumn{2}{c|}{ Resistance of the related cross section related with level1 } \\
\hline $\begin{array}{c}\text { Moment of the bottom } \\
\text { cross section }\end{array}$ & $\begin{array}{c}\text { Shearing force of the } \\
\text { bottom cross section }\end{array}$ & $\begin{array}{c}\text { Moment resistance of } \\
\text { right section }\end{array}$ & $\begin{array}{c}\text { Axial Resistance of } \\
\text { right section }\end{array}$ & $\begin{array}{c}\text { Shearing resistance of } \\
\text { inclined section }\end{array}$ \\
\hline$(\mathrm{kN} m)$ & $(\mathrm{kN})$ & $(\mathrm{kN} \mathrm{m})$ & 857.5 & 1883.0 \\
\hline 13007.6 & 1338.6 & 2523.8 & 1155.5 & 1875.5 \\
\hline 9446.9 & 592.0 & 2670.3 & 1707.0 & 1909.1 \\
\hline 7069.6 & 392.9 & 2929.7 & 1831.5 & 1912.5 \\
\hline 6565.5 & 359.6 & 2986.1 & 1513.3 & 1894.3 \\
\hline 7648.7 & 434.8 & 2840.3 & 883.5 & 1878.1 \\
\hline 12555.2 & 1548.0 & 2536.7 & & \\
\hline
\end{tabular}


It can be concluded from Table 15. as follows:

(a)The earthquake force provided by the <China JTJ044-89> is approximately equal to that by the E1 in the <China JTG/TB02-01-2008>. In other words, the earthquake effect provided by the China old seismic specification just equals to the low scale earthquake provided by the revised one;

(b)All columns are safety under the $\mathrm{E}_{\mathrm{hp}}$ provided by the <China JTJ044-89> and the E1 by the <China JTG/T B02-01-2008>, the safety factors of the resistance of moment, shearing force and axial force are more than $1.5,1.5$ and 6 respectively. Meanwhile the structure is beyond the limit of elastic stage of columns under the Level 1 provided by the<Japan JRA-2002> for the external moment and shearing force nearly are 2 5 times of the resistance of elastic stage, that is considered as not enough and unsafe seismic resistance.

(5) Structural analysis by strong earthquake by static

\section{method}

The structure is considered to enter plastic stage under a strong earthquake and the calculation result is shown in Table 17. Moreover the rubber support deformation is safety evaluated under the E2 according to the <China JTG/TB02-01-2008> as shown in Table 16.

Table 16. Support deformation evaluation under E2 effect

\begin{tabular}{|c|c|c|}
\hline $\begin{array}{l}\text { Support location } \\
\text { (the S.N. of } \\
\text { column related) }\end{array}$ & $\begin{array}{l}\text { Deformation } \\
\text { (m) }\end{array}$ & Safety evaluation \\
\hline 1 & 4.9 & \multirow{6}{*}{$\begin{array}{l}\text { The permissible } \\
\text { maximum } \\
\text { deformation of this } \\
\text { type of rubber } \\
\text { support is } 7.7 \mathrm{~cm} \text {, } \\
\text { so it's OK! }\end{array}$} \\
\hline 2 & 2.0 & \\
\hline 3 & 0.7 & \\
\hline 4 & 0.5 & \\
\hline 5 & 0.9 & \\
\hline 6 & 6.0 & \\
\hline
\end{tabular}

Table 17. The evaluation of the No.6 column under strong earthquake

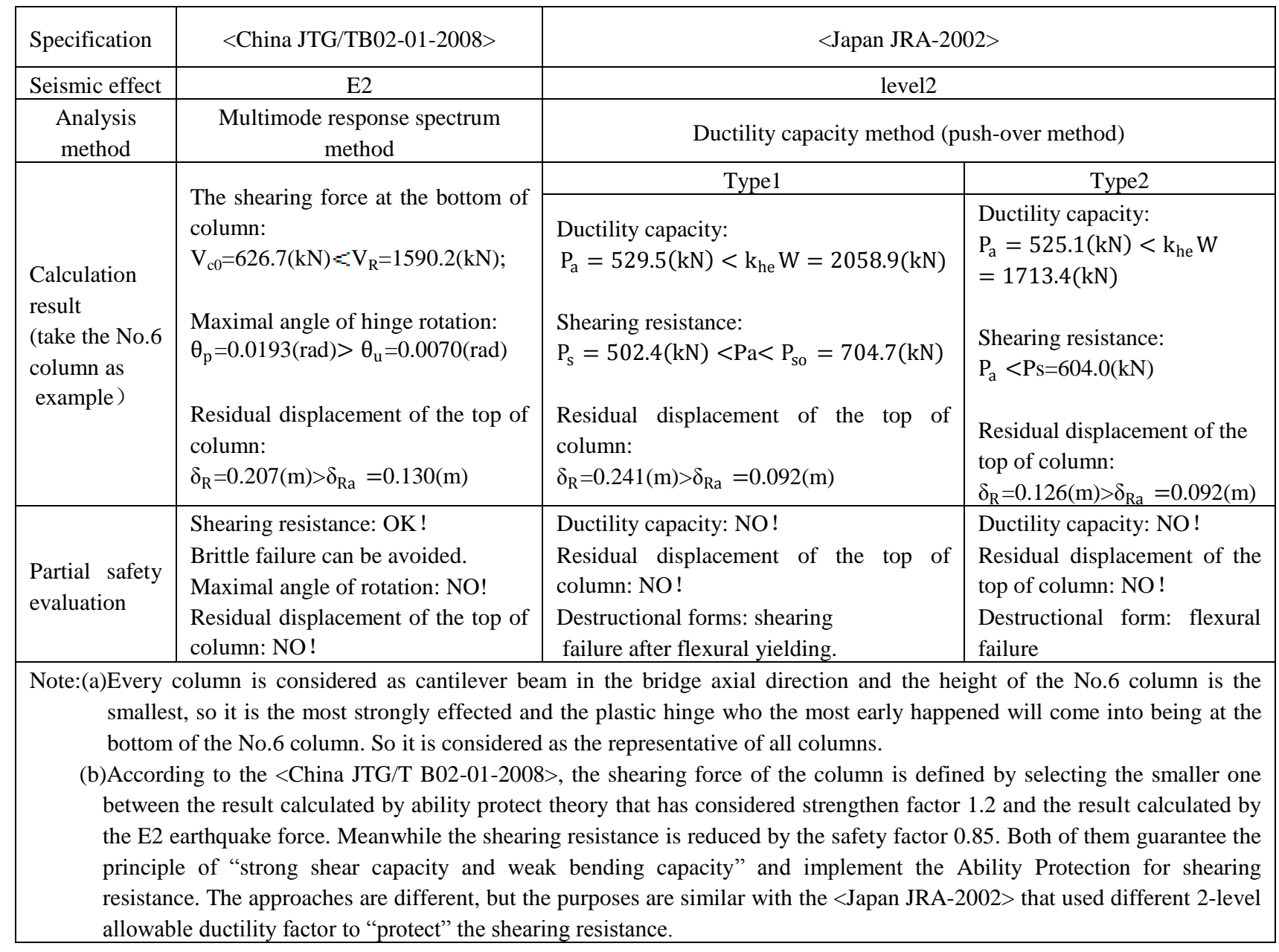

(6) Structural analysis by strong earthquake by TimeHistory method

From the conclusion of 4.(5), the restriction at some level to the displacement of superstructure by abutments is considered to tap seismic potential of the structure and obtain more realistic result.

The restriction from the gravity abutments in both sides and the earth filled behind them are replaced at the abutment locations to two horizontal linear springs with an $8 \mathrm{~cm}$ gap between the superstructure and the spring 
according to the size of expansion joints there. To every column three stages elastic-plastic mechanical strength characteristic is assigned. The potential plastic hinges also are assigned to the bottoms of every column.

The model is calculated by the T2-III-1(1995, HYOUGOKEN_South, N12W). When the assumptive largest displacement of the top of the No.6 column reaches $12.7 \mathrm{~cm}$ (the given displacement superposed by the gaps from the expansion joint and the experiential deform of abutment), moreover the maximum moment of the plastic hinge at the bottom of the No.6 column is controlled: $\mathrm{M}_{\max }=4522(\mathrm{kN} \cdot \mathrm{m})<\mathrm{M}_{\mathrm{u}}=4844.8(\mathrm{kN} \cdot \mathrm{m})$ by the adjustment of the spring stiffness of between the

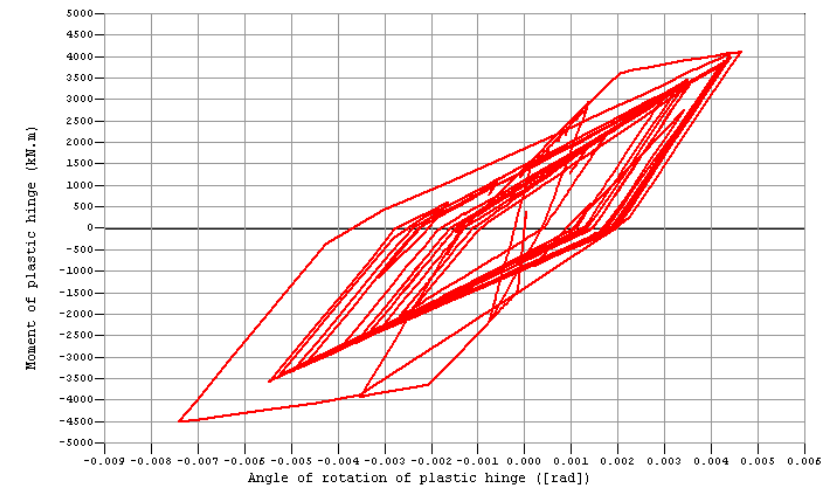

Fig.17. Skeleton curve between moment and angle of rotation of the plastic hinge at the bottom of the No.6 column

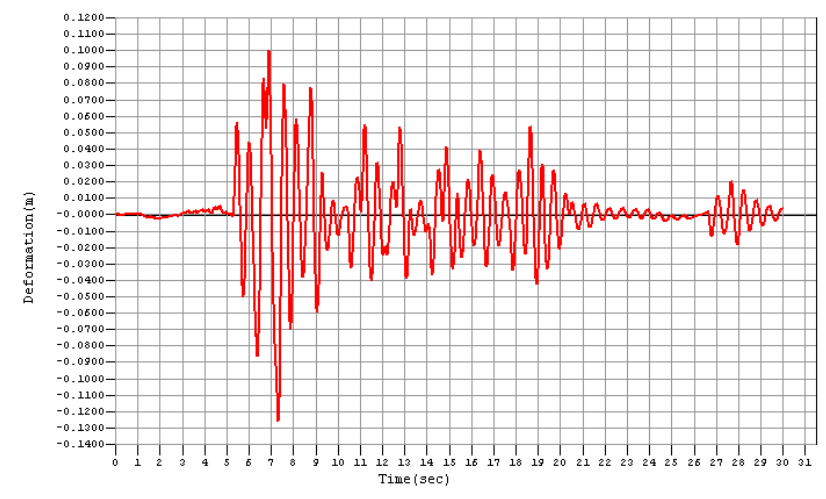

Fig.18. Time-history of the deformation at the rubber support on the No.4 column

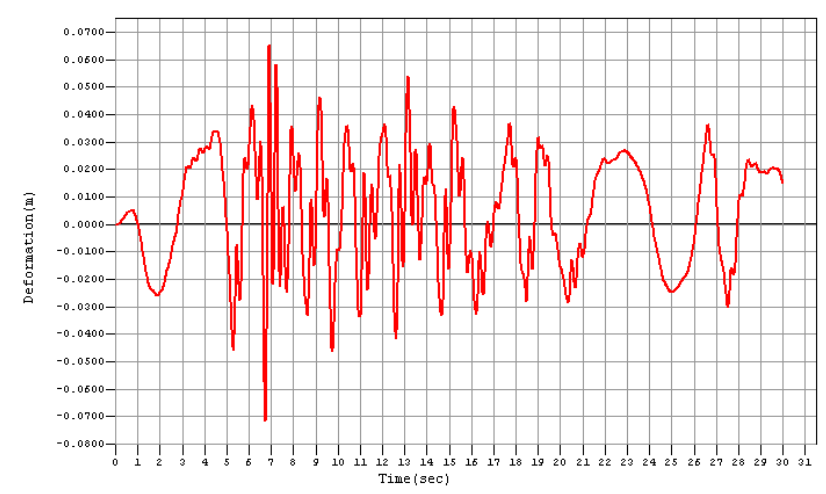

Fig.19. Time-history of the deformation at the rubber support on the No.6 column

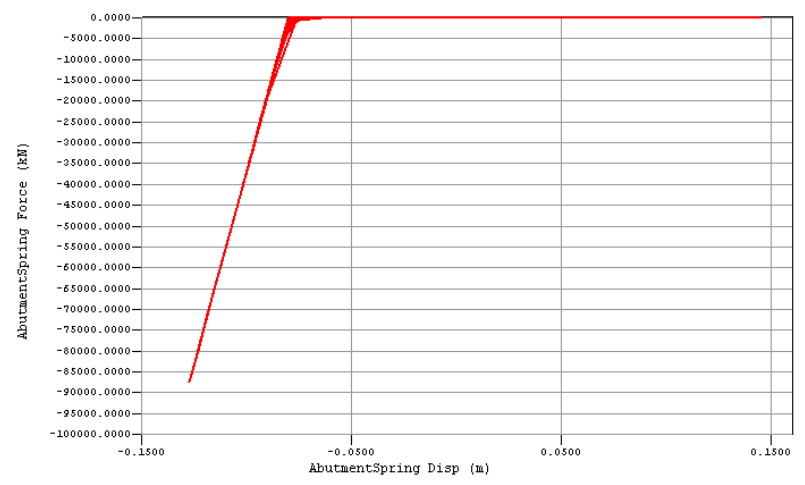

Fig.20. Time-history of the spring force between superstructure and abutment

superstructure and the abutments as shown in Fig.17..

Meanwhile, the time-history skeleton of deformations of the rubber support that lie on the bent cap upon the No.4 and No.6 column are typically shown in Fig.18. and Fig.19. From them it can be seen that the maximum deformation on the No.4 whose column is the highest is $12.5 \mathrm{~cm}$ and beyond the permissible maximum value of $7.7 \mathrm{~cm}$, while that on the No.6 whose column is the shortest is $7.1 \mathrm{~cm}$ and within the permissible range.

However the maximum force of the spring mentioned has reach $87420(\mathrm{kN})$ as in Fig.20. shown. The huge acting force (impulse) has gone well beyond the capacity for acceptance of not only the abutments but also the ends of the superstructure. It is considered the abutments though can restrict the displacement of the superstructure and reduce the moment of column at some level, it cannot improve the seismic ability of the structure to reach safety level and the structure still is in dangerous under this kind of strong earthquake.

\section{CONCLUSION}

1)The seismic performance level of the bridges whose seismic design was implemented before Oct $1^{\text {st }} 2008$ according to the <China JT044-89> only equals to the performance for the low scale earthquake (E1) provided in the <JTG/T B02-01-2008> and cannot meet the requirement of the 3-level performance. It also has not provisions of the checking for displacement, the guarantee for ductility ability and the concept for the ability protection. The provisions in it concerning seismic detail design and resistant measure is unambiguous. For reason given above, the seismic resistance of many large highway bridges in Yunnan are not enough, including many expressway bridges accomplished not long ago and there is possibly potential safety hazard especially when a strong earthquake happens.

2) In strong earthquake conditions, the moment resistance of the column is less than the moment caused by earthquake, while the shearing resistance is enough. As such, the failure pattern is deduced as flexural failure and the brittle failure form can be avoided, that is considered is more reasonable for 
safety. When the plastic hinge has come into being in the bottom of some columns, at least one of them the horizontal displacement of the top and the maximum angle of rotation of the hinge have gone beyond the maximum limit of both of the two specifications. It is also concluded that the large deformation will cause the bridge function failure.

3) The Chinese seismic structural theory and specification that is still imperfect in comparison with the Japanese one, it should widely borrow ideas from foreign advanced theory and experience and been continuously supplemented and improved. On the other hand, the bridges that have been constructed or completed to traffic should be in a planned way and with focuses seismic recalculated, checked and reinforced according to the new <JTG/T B02-01-2008> and some foreign reasonable successful experience, especially the bridges in the "lifeline" highway lie on higher seismic intensity zones.

\section{REFERENCES}

1) Seismic ground motion parameter zonation map of China, GB 18306-2001, State Bureau of Quality and Technical Supervision of China,2001.2.2

2) Specifications of Earthquake Resistant Design for Highway Engineering, JTJ004-89, Ministry of Communications of the People's Republic of China,1990.1.1.

3) Guidelines for Seismic Design of Highway Bridge, JTG/T B02-01-2008, Ministry of Communications and transport of the People's Republic of China.2008.10.1

4) Specification for Japanese Highway Bridges, part V seismic design, Japan Road Association, 2002.

5) Code for Design of Highway Reinforced Concrete and Prestressed Concrete Bridges and Culverts, JTG D62-2004 Ministry of Communications of the People's Republic of China,2004.10.1

6) The Examples of Design and Calculation for Highway Bridge, the editorial committee of The Examples of Design and Calculation for Highway Bridge, the SANKAIDOU press, 2000

7) Bridge Seismic Research, Wang Kehai, China Railway Press, 2007. 